\title{
SNPs associated with barley resistance to isolates of Pyrenophora teres f. teres
}

Irina V. Rozanova ${ }^{1,2^{*}}$, Nina M. Lashina ${ }^{3}$, Zakhar S. Mustafin ${ }^{1}$, Sofia A. Gorobets ${ }^{1}$, Vadim M. Efimov ${ }^{1,4}$ Olga S. Afanasenko ${ }^{3}$ and Elena K. Khlestkina ${ }^{1,2}$

From 11th International Multiconference "Bioinformatics of Genome Regulation and StructurelSystems Biology" - BGRSISB2018 Novosibirsk, Russia. 20-25 August 2018

\begin{abstract}
Background: Net blotch caused by Pyrenophra teres f. teres is a major foliar disease of barley. Infection can result in significant yield losses of susceptible cultivars of up to $40 \%$. Of the two forms of net blotch (P. teres $\mathrm{f}$. teres and $P$. teres f. maculata), P. teres f. teres (net form of net blotch) is the dominant one in Russia. The goal of the current study was to identify genomic regions associated with seedling resistance to several pathotypes of the net form of net blotch in Siberian spring barley genotypes. For this, a genome-wide association study of a Siberian barley collection, genotyped with $50 \mathrm{~K}$ Illumina SNP-chip, was carried out.

Results: Seedling resistance of 94 spring barley cultivars and lines to four Pyrenophora teres $\mathrm{f}$. teres isolates (S10.2, K5.1, P3.4.0, and A2.6.0) was investigated. According to the Tekauz rating scale, 25, 21, 14, and 14\% of genotypes were highly resistant, and 19,8,9, and 16\% of genotypes were moderate-resistant to the isolates S10.2, K5.1, P3.4.0, and A2.6.0, respectively. Eleven genotypes (Alag-Erdene, Alan-Bulag, L-259/528, Kedr, Krymchak 55, Omsky golozyorny 2, Omsky 13709, Narymchanin, Pallidum 394, Severny and Viner) were resistant to all studied isolates. Nine additional cultivars (Aley, Barkhatny, Belogorsky, Bezenchuksky 2, Emelya, G-19980, Merit 57, Mestny Primorsky, Slavaynsky) were resistant to 3 of the 4 isolates. The phenotyping and genotyping data were analysed using several statistical models: $G L M+Q, G L M+P C A, G L M+P C A+Q$, and the MLM + kinship matrix. In total, 40 SNPs in seven genomic regions associated with net blotch resistance were revealed: the region on chromosome $1 \mathrm{H}$ between 57.3 and 62.8 CM associated with resistance to 2 isolates (to P3.4.0 at the significant and K5.1 at the suggestive levels), the region on chromosome $6 \mathrm{H}$ between 52.6 and $55.4 \mathrm{cM}$ associated with resistance to 3 isolates (to P3.4.0 at the significant and $\mathrm{K} 5.1$ and $\mathrm{S} 10.2$ at the suggestive levels), three isolate-specific significant regions (P3.4.0-specific regions on chromosome $2 \mathrm{H}$ between 71.0 and $74.1 \mathrm{cM}$ and on chromosome $3 \mathrm{H}$ between 12.1 and $17.4 \mathrm{cM}$, and the A2.6.0-specific region on chromosome $3 \mathrm{H}$ between 50.9 and $54.8 \mathrm{cM}$ ), as well as two additional regions on chromosomes $2 \mathrm{H}$ (between 23.2 and $23.8 \mathrm{cM}$, resistant to S10.2) and 3 (between 135.6 and $137.5 \mathrm{cM}$ resistant to $\mathrm{K} 5.1$ ) with suggestive SNPS, coinciding, however, with known net blotch resistance quantitative trait loci (QTLS) at the same regions.

\footnotetext{
* Correspondence: bykova@bionet.nsc.ru

'Institute of Cytology and Genetics, Siberian Branch of the Russian Academy

of Sciences, Lavrentjeva Ave. 10, Novosibirsk 630090, Russia

${ }^{2}$ N.I. Vavilov All-Russian Research Institute of Plant Genetic Resources (VIR), St.

Petersburg 190000, Russia

Full list of author information is available at the end of the article
}

(c) The Author(s). 2019 Open Access This article is distributed under the terms of the Creative Commons Attribution 4.0 International License (http://creativecommons.org/licenses/by/4.0/), which permits unrestricted use, distribution, and reproduction in any medium, provided you give appropriate credit to the original author(s) and the source, provide a link to the Creative Commons license, and indicate if changes were made. The Creative Commons Public Domain Dedication waiver (http://creativecommons.org/publicdomain/zero/1.0/) applies to the data made available in this article, unless otherwise stated. 


\begin{abstract}
(Continued from previous page)
Conclusions: Seven genomic regions on chromosomes $1 \mathrm{H}, 2 \mathrm{H}, 3 \mathrm{H}$, and $6 \mathrm{H}$ associated with the resistance to four Pyrenophora teres $\mathrm{f}$. teres isolates were identified in a genome-wide association study of a Siberian spring barley panel. One novel isolate-specific locus on chromosome 3 between 12.1 and $17.4 \mathrm{cM}$ was revealed. Other regions identified in the current study coincided with previously known loci conferring resistance to net blotch. The significant SNPs revealed in the current study can be converted to convenient PCR markers for accelerated breeding of resistant barley cultivars.
\end{abstract}

Keywords: Association mapping, Barley, GWAS, Hordeum vulgare, Net blotch, Resistance, SNP

\section{Background}

Net blotch, caused by Pyrenophora teres (anamorph: Drechslera teres [Sacc.] Shoem.), is a major foliar disease of barley worldwide and in Russia. The pathogen exists in two forms based on the symptoms they cause: the net form of net blotch (P. teres f. teres) and the spot form of net blotch ( $P$. teres f. maculata). The net form of net blotch (NFNB) is the dominant form in different regions of Russia; the spot form of net blotch (SFNB) was found only in the southern part of European Russia [1]. NFNB epidemics in Northwest Russia appear with a frequency of 5 times every 10 years [2]. Infection can result in significant yield losses of up to $40 \%$ on susceptible cultivars under favourable environmental conditions [3]; also, the disease can cause reductions in the quality of barley [4].

The most cost-effective and environmentally friendly way to control the disease is the development of resistant cultivars. The success of resistance breeding relies on the genetic diversity of resistance and the availability of resistance genes in locally adapted germplasm.

The genomic regions associated with resistance of barley to P. teres $\mathrm{f}$. teres have been found on all barley chromosomes [3, 5-18] using both linkage mapping in biparental mapping populations and association mapping (AM). Some QTLs provide resistance during whole ontogenesis, such as QRpt6 on chromosome $6 \mathrm{H}$, determining both seedling and adult resistance to the net form of net blotch [5]. Other QTLs appear to be either seedling- or adult-specific [19]. Among the genomic regions associated with $P$. teres $f$. teres resistance, the region on chromosome $6 \mathrm{H}$ is the most well studied. It is supposed that either 3 different alleles of a single locus or three closely linked resistant genes exist in this region [9].

The goal of the current study was to identify genomic regions associated with seedling resistance to several pathotypes of the net form of net blotch. For this, a genome-wide association study of a Siberian barley collection, genotyped with 50 K Illumina SNP-chip, was carried out.

\section{Materials and methods}

\section{Plant material and genotyping data}

The study was based on a Siberian barley panel, consisting of 94 spring cultivars and breeding lines from the
ICG GenAgro collection (Novosibirsk, Russia). Half of this panel was represented by cultivars and lines developed in breeding centres located in Siberia, whereas the other half consisted of cultivars and lines maintained in the Siberian spring barley collection, but originating from other regions and countries. Genotyping data for these 94 cultivars and lines were available from our previous study [20]. Additional information on $50 \mathrm{~K}$ Illumina SNP-chip loci was extracted from [21] and the BARLEYMAP resource (http://floresta.eead.csic.es/barleymap).

\section{Pathogen isolates and culture conditions}

For phenotyping, four Pyrenophora teres f. teres single conidia isolates were used: S10.2 (Finland), K5.1 (Russia, Leningrad region), P3.4.0 (Russia, Leningrad region), and A2.6.0 (Russia, Astrakhan region). Arguments for choosing certain isolates were different origins and good sporulation ability.

Propagation of the P. teres isolates was conducted on Czapek's modified medium containing $0.5 \mathrm{~g} / \mathrm{L}$ $\mathrm{KH}_{2} \mathrm{PO}_{4}, 0.5 \mathrm{~g} / \mathrm{L} \mathrm{MgSO}_{4}, 0.5 \mathrm{~g} / \mathrm{L} \mathrm{KCl}, 1.2 \mathrm{~g} / \mathrm{L}$ urea, 20 $\mathrm{g} / \mathrm{L}$ lactose, and $20 \mathrm{~g} / \mathrm{L}$ agar. To produce inoculum, single spore cultures were grown under near ultraviolet (UV) light with a $12 \mathrm{~h}$ photoperiod at $18-20^{\circ} \mathrm{C}$ for 14 days. Conidia were harvested by adding distilled water to the plate and scraping the agar surface with a spatula. The suspension was filtered through two layers of cheesecloth to remove fragments of mycelia. The concentration of the inoculum was adjusted to 5000 conidia per $\mathrm{ml}$. The surfactant Tween 20 was added $(100 \mu \mathrm{l}$ per litre) to facilitate dispersion of the inoculum over the leaf surfaces. Inoculation was completed by spraying at a rate of approximately $0.2 \mathrm{ml}$ per plant.

\section{Plant growing and disease assessment}

Seedling resistance was evaluated in controlled conditions in a climate chamber in the All-Russian Research Institute for Plant Protection (St. Petersburg, Russia). Three seeds of each barley cultivar were sown per pot containing nutrient-supplemented peat and cultivated for 2 weeks at $20-22{ }^{\circ} \mathrm{C}$ with a photoperiod $16 \mathrm{~h}$ light 
(exposure $5000 \mathrm{~lx}) / 8 \mathrm{~h}$ darkness in a split-plot design with three replicates. After inoculation, plants were covered with plastic bags and placed for $48 \mathrm{~h}$ at 20$22{ }^{\circ} \mathrm{C}$ without light. After 2 days, inoculated plants were placed at $20-22^{\circ} \mathrm{C}$ with a photoperiod $16 \mathrm{~h}$ light (exposure $5000 \mathrm{~lx}$ ) $/ 8 \mathrm{~h}$ darkness and air humidity of $60-70 \%$ and were grown till the disease assessment. Seedling infection responses (IRs) were assessed on the second leaf 10-12 days after inoculation. P. teres resistance was scored by using the 10-point scale of Tekauz [22] $1-3=$ highly resistant (HR); 3.1-5.0= moderately resistant (MR); 5.1-6.9= moderately susceptible (MS); 7.0-10.0 = high susceptible (HS).

\section{Population structure}

The population structure was analysed using STRUCTURE v 2.3.4 [23] based on the genotypic data of a subset of 13,659 markers. Each second marker of a set of 27,319 markers previously selected by quality control [20] was taken to reduce the computing time. The number of subpopulation ( $\mathrm{k}$ ) in the panel was inferred using an admixture model with correlated allele frequencies, a burn-in period length of 5000 and 5000 Markov chain Monte Carlo (MCMC) repetitions. Independent analyses were run for each $\mathrm{k}$ between 1 and 32. The estimated likelihood values $[\mathrm{LnP}(\mathrm{D})]$ were compared with $\mathrm{k}$ using a graph to determine the optimal $\mathrm{k}$.

\section{Association analysis}

Different statistical models were tested on disease resistance scores (separately for each of four isolates) with the help of the TASSEL 5 package [24] to detect significant marker associations: (1) generalized liner model (GLM) without correction for population structure; (2) GLM + Q: GLM + Q-matrix to account for population structure; (3) GLM + PCA: GLM with a principal component analysis (PCA) to account for population structure, (4) GLM + PCA + Q; and (5) MLM + K: MLM with kinship matrix. Genotyping data for a set of 27,319 markers previously selected by quality control [20] were used in the association analysis.

To identify significant single nucleotide polymorphisms (SNPs), two corrections were used: (i) the Bonferroni correction, where the significant threshold (0.05) is divided by the total number of tests, in this case, the total number of markers $(27,319)$, giving the threshold $1.8302 * 10^{-6}$, and (ii) the false discovered rate (FDR) that was calculated for each isolate in each model. The suggestive level corresponded to $p<10^{-4 \text { th }}$ and was considered as suggestive evidence of an association if SNPs in the model of an isolate did not exceed the threshold value.

\section{Results}

\section{Phenotyping}

The results of the investigation of the seedling resistance to four net blotch isolates are given in Additional file 1 and summarized in Fig. 1. According to the Tekauz rating scale, $25,21,14$, and $14 \%$ of genotypes were highly resistant and 19, 8, 9, and $16 \%$ of genotypes were moderately resistant to the isolates S10.2, K5.1, P3.4.0, and A2.6.0, respectively. Eleven genotypes (Alag-Erdene, Alan-Bulag, L-259/528, Kedr, Krymchak 55, Omsky golozyorny 2, Omsky 13709, Narymchanin, Pallidum 394, Severny and Viner) were resistant to all studied isolates. Nine additional cultivars (Aley, Barkhatny, Belogorsky, Bezenchuksky 2, Emelya, G-19980, Merit 57, Mestny Primorsky, Slavaynsky) were resistant to 3 of the 4 isolates.

\section{Population structure}

The most likely number of subpopulations was $\mathrm{k}=4$ as determined by STRUCTURE v 2.3.4 (Fig. 2). The set of barley genotypes was divided into 4 groups (Fig. 3) consisting of $17,29,20$, and $34 \%$ of genotypes. Group III contained the highest percentage of Siberian accessions (67\%). Groups I, II and IV contained 31, 30 and 39\% of Siberian accessions, respectively (Table 1). Percentages of highly resistant (HR), moderately resistant (MR), moderately susceptible (MS), and highly susceptible (HS) genotypes in each group is given in Table 1.

\section{Genome-wide association study (GWAS) analysis}

The results of all statistical models were first compared in quantile-quantile (QQ) plot to find proper models for each dataset. QQ-plots for the models used are presented for each $P$. teres f. teres isolate in Additional file 2. The GLM analysis without correction for population structure showed a great number of false positive SNPs in a QQ-plot (Additional file 2). A QQ-plot using the GLM model accounting for population structure (GLM + Q) appeared to be more proper; in the case of the P.3.4.0 isolate, a very good match with expected values was observed (Additional file 2). Similarly, the GLM + PCA and GLM + PCA + Q models appeared to be more proper than GLM. Association mapping results using different models are presented in Additional file 3. With the help of the GLM + Q model, two significant SNPs on chromosome $6 \mathrm{H}$ were revealed for the isolate P3.4.0, one significant SNP on chromosome $3 \mathrm{H}$ for the isolate A2.6.0, one suggestive SNP on chromosome $1 \mathrm{H}$ for the isolate K5.1 and two suggestive SNPs (1 SNP on chromosome $2 \mathrm{H}$ and $1 \mathrm{SNP}$ on chromosome $5 \mathrm{H}$ ) for isolate S10.2 (Additional file 3; Table 2).

The GLM analysis with PCA accounting for the population structure (GLM + PCA) revealed 2 significant SNPs on chromosome $6 \mathrm{H}$ and 2 significant SNPs on 


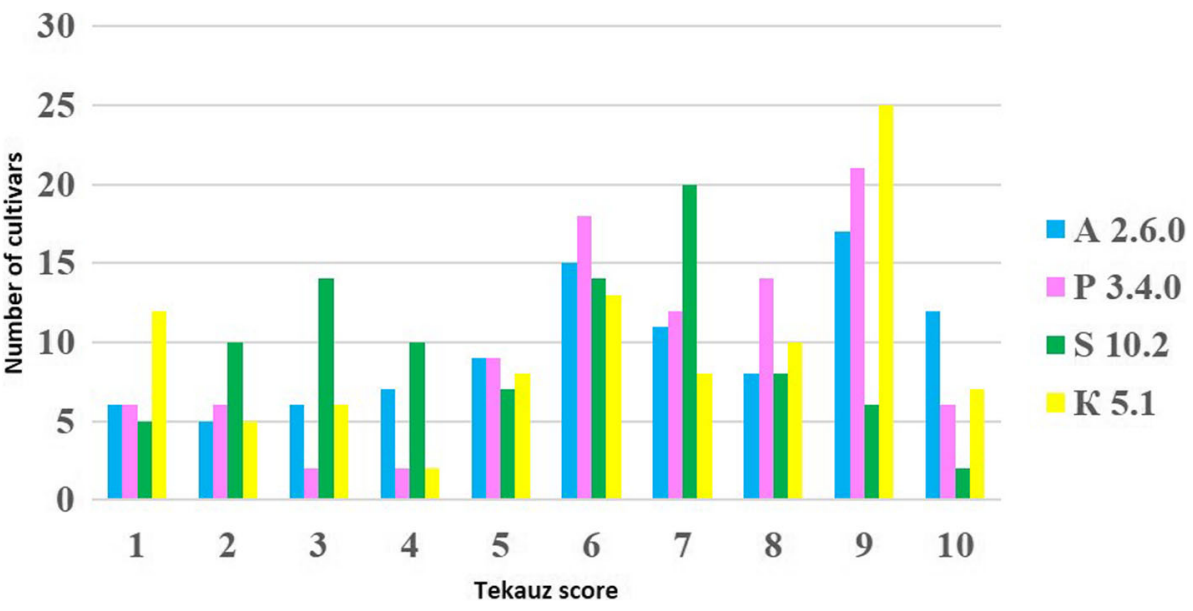

Fig. 1 Frequency distributions for disease responses in seedling inoculations with four different P. teres f.teres isolates A 2.6.0, P 3.4.0, S10.2, K5.1

chromosome $2 \mathrm{H}$ associated with resistance to the isolate P.3.4.0. Additionally, 2 suggestive SNPs (1 SNP on chromosome $3 \mathrm{H}$ and $1 \mathrm{SNP}$ on chromosome $6 \mathrm{H}$ close to the region revealed for P3.4.0 isolate) were associated with resistance to the $\mathrm{K} 5.1$ isolate, and 3 suggestive SNPs on chromosome $6 \mathrm{H}$ were associated with resistance to S10.2 (Additional file 3; Table 3).

The GLM analysis with a combination of two corrections $\mathrm{GLM}+\mathrm{PCA}+\mathrm{Q}$ revealed 7 significant SNPs on chromosome $6 \mathrm{H}, 7$ significant SNPs on chromosome $2 \mathrm{H}, 8 \mathrm{SNP}$ on chromosome $1 \mathrm{H}$ and 6 significant SNPs on chromosome 3H (Additional file 3; Table 4).

No significant SNP was revealed using the MLM analysis with the kinship matrix (MLM + K model).

\section{Discussion}

The analysis of the population structure of the Siberian barley panel revealed 4 clusters. We noticed that among
14 accessions susceptible to all four net blotch isolates, 8 originated from Siberia (57.1\%), and among 23 accessions susceptible to three isolates, 5 (22\%) originated in Siberia.

The GWAS performed using five statistical models revealed seven genomic loci associated with resistance to one to three net blotch isolates. The comparison of these regions with locations of previously known $P$. teres resistance QTLs is presented in Table 5.

\section{Chromosome $1 \mathrm{H}$}

Nine SNPs that were detected on chromosome $1 \mathrm{H}$ in the current study are associated with resistance to the P3.4.0 and K5.1 isolates. They are located in the interval $57.3-62.8 \mathrm{cM}$ and expanded between markers JHIHv50k-2016-33086 and JHI-Hv50k-2016-36398. Earlier, Grewal et al. (2012) [10] revealed locus between 52.4$56.8 \mathrm{cM}$, while Afanasenko et al. (2014) [2] reported

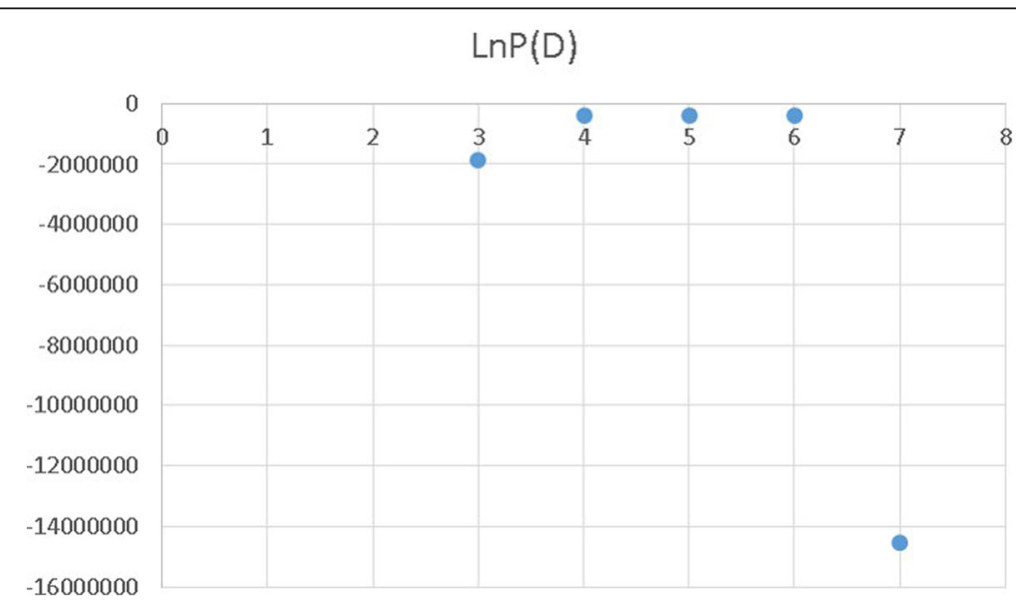

Fig. 2 The most likely number of subpopulations was $k=4$ determined by STRUCTURE $v$ 2.3.4 The estimated likelihood values [LnP(D)] were compared with $\mathrm{k}$ using graph to determine the optimal $\mathrm{k}(\mathrm{k}=4)$ 


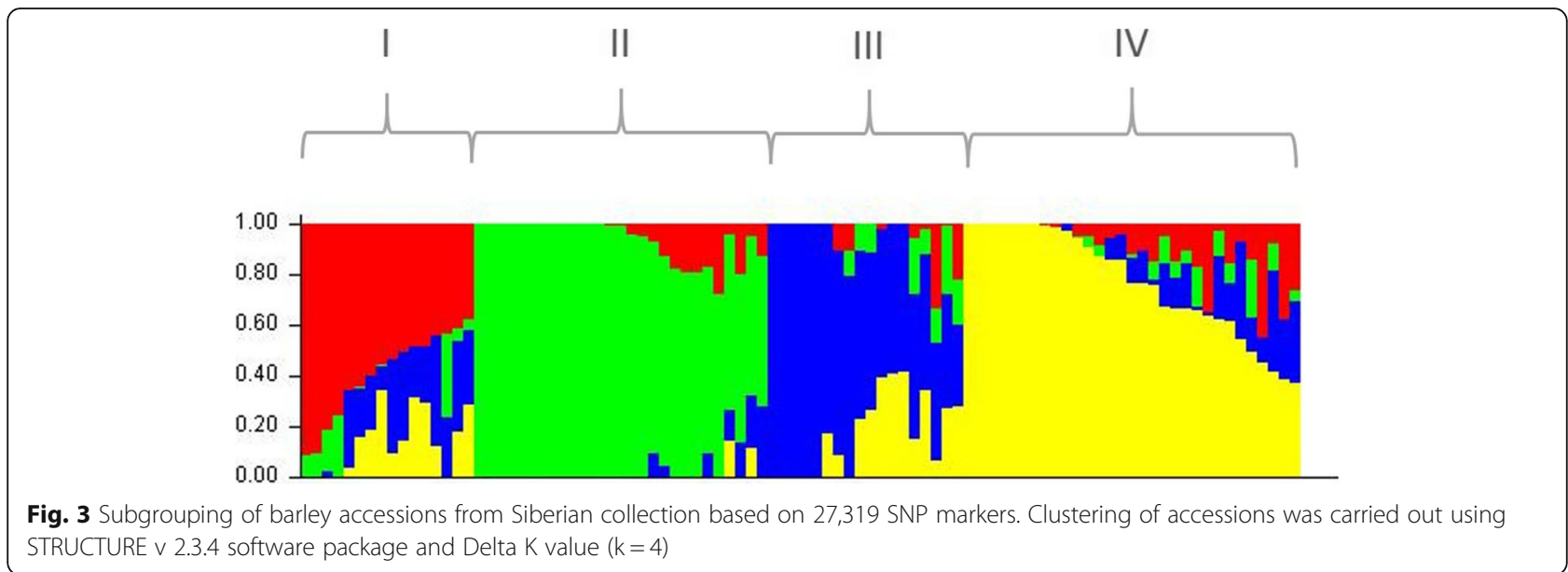

QTLs between 50 and $86 \mathrm{cM}$ on this chromosome. We suggest that seedling resistance to the newly studied isolates P3.4.0 and K5.1 is conferred in Siberian barley germplasm by the previously known locus found on chromosome $1 \mathrm{H}$ by Grewal et al. (2012) [10] and Afanasenko et al. (2014) [2]. In addition, chromosome $1 \mathrm{H}$ is known to carry another locus at approximately $40 \mathrm{cM}$ from this one, described by Amezrou et al. (2018) [8] and Vatter et al. [18] (Table 5).

\section{Chromosome $2 \mathrm{H}$}

The resistance to different isolates P3.4.0 and S10.2 was associated with two different loci. The locus associated with resistance to the S10.2 isolate included one suggestive SNP (JHI-Hv50k-2016-74407) mapped in the interval 23.3-23.8 cM. We suggest that seedling resistance to the S10.2 isolate is conferred by a previously known locus mapped earlier by Wonneberger et al. (2017) [7] and Vatter et al. (2017) [18] (Table 5). The locus on chromosome $2 \mathrm{H}$ revealed for the P3.4.0 isolate included 7 SNPs and was expanded between JHI-Hv50k-2016-104508 and JHI-Hv50k-2016-104859 markers located in the interval $71.0-74.1 \mathrm{cM}$. This region coincides with location of the previously described QTL mapped between 51 and $75 \mathrm{cM}$ by Afanasenko et al. (2014) [2]. The locus detected by König et al. (2014) [25] between 75 and $80 \mathrm{cM}$ can be the

Table 1 Percentage content of susceptible and resistant to net blotch accessions in four clusters obtained with population structure analysis

\begin{tabular}{|c|c|c|c|c|c|c|c|}
\hline Group & $\begin{array}{l}\text { Percentage of genotypes } \\
\text { from the total number (\%) }\end{array}$ & $\begin{array}{l}\text { Percentage of Siberian } \\
\text { accessions in the group (\%) }\end{array}$ & $\begin{array}{l}\text { Evaluation of } \\
\text { resistance }\end{array}$ & $\begin{array}{l}\text { Isolate } \\
\text { S10.2 (\%) }\end{array}$ & $\begin{array}{l}\text { Isolate } \\
\text { K5.1 } \\
(\%)\end{array}$ & $\begin{array}{l}\text { Isolate } \\
\text { P3.4.0 } \\
(\%)\end{array}$ & $\begin{array}{l}\text { Isolate } \\
\text { A2.6.0 } \\
(\%)\end{array}$ \\
\hline \multirow[t]{4}{*}{ Group I } & 17 & 31 & $\mathrm{HR}$ & 12.5 & 25 & 19 & 25 \\
\hline & & & $M R$ & 31 & 12.5 & 12.5 & 6 \\
\hline & & & MS & 31 & 25 & 31 & 6 \\
\hline & & & $\mathrm{HS}$ & 25 & 37.5 & 44 & 32.5 \\
\hline \multirow[t]{4}{*}{ Group ॥ } & 29 & 30 & $H R$ & 37 & 37 & 15 & 18.5 \\
\hline & & & $M R$ & 11 & 11 & 7 & 26 \\
\hline & & & MS & 22 & 4 & 22 & 26 \\
\hline & & & $\mathrm{HS}$ & 30 & 48 & 56 & 30 \\
\hline \multirow[t]{4}{*}{ Group III } & 20 & 67 & $H R$ & 11 & 6 & 6 & 6 \\
\hline & & & $M R$ & 22 & 6 & 11 & 11 \\
\hline & & & MS & 17 & 22 & 22 & 11 \\
\hline & & & $\mathrm{HS}$ & 50 & 67 & 67 & 72 \\
\hline \multirow[t]{4}{*}{ Group IV } & 34 & 39 & $H R$ & 29 & 16 & 16 & 10 \\
\hline & & & $M R$ & 19 & 6.5 & 10 & 16 \\
\hline & & & MS & 10 & 26 & 13 & 26 \\
\hline & & & $\mathrm{HS}$ & 42 & 52 & 58 & 48 \\
\hline
\end{tabular}


Table 2 SNPs associated with resistance to the isolates A2.6.0, P3.4.0, K5.1 and S10.2, revealed by GLM analysis with accounting of population structure (GLM $+Q$ model)

\begin{tabular}{|c|c|c|c|c|c|c|c|c|}
\hline Isolate & $p$-value & Marker & Chr & Position & $\mathrm{CM}$ & Allele & Minor Allele & SNP associated with resistance \\
\hline A2.6.0 & $1.01 \mathrm{E}-06$ & $J H I-H v 50 k-2016-183207^{a}$ & $3 \mathrm{H}$ & 490244247 & $52.6-54.8$ & $\mathrm{~A} / \mathrm{T}$ & $\mathrm{T}(0.41)$ & $\mathrm{T}(0.75)$ \\
\hline P3.4.0 & $8.11 \mathrm{E}-08$ & SCRI_RS_239642 ${ }^{\mathrm{a}}$ & $6 \mathrm{H}$ & 357492232 & 55.4 & $A / G$ & $\mathrm{~A}(0.22)$ & $A(0.83)$ \\
\hline P3.4.0 & 2.09E-07 & SCRI_RS_224389 ${ }^{a}$ & $6 \mathrm{H}$ & 360336381 & 55.4 & $\mathrm{C} / \mathrm{T}$ & $C(0.22)$ & $C(0.83)$ \\
\hline K5.1 & $5.89 \mathrm{E}-6$ & JHI-Hv50k-2016-33160 b & $1 \mathrm{H}$ & 441912080 & $57.3-58.2$ & $\mathrm{G} / \mathrm{A}$ & $A(0.21)$ & $G(0.95)$ \\
\hline S10.2 & $1.82 \mathrm{E}-05$ & JHI-Hv50k-2016-74407 & $2 \mathrm{H}$ & 31977763 & $23.2-23.8$ & $\mathrm{C} / \mathrm{T}$ & $C(0.46)$ & $\mathrm{T}(0.68)$ \\
\hline S10.2 & 2.89E-05 & BOPA1_5206-787 ${ }^{\mathrm{b}}$ & $5 \mathrm{H}$ & 1154245 & NA & $\mathrm{G} / \mathrm{C}$ & $\mathrm{G}(0.14)$ & $C(1)$ \\
\hline S10.2 & 4.95E-05 & $J H I-H v 50 k-2016-391875^{b}$ & $6 \mathrm{H}$ & 142513704 & $52.6-53.8$ & $\mathrm{~A} / \mathrm{C}$ & $\mathrm{A}(0.30)$ & $C(1)$ \\
\hline$S 10.2$ & $4.95 \mathrm{E}-05$ & BOPA2_12_30021 ${ }^{\mathrm{b}}$ & $6 \mathrm{H}$ & 156957594 & & $\mathrm{~A} / \mathrm{G}$ & $\mathrm{A}(0.30)$ & $G(1)$ \\
\hline
\end{tabular}

${ }^{\mathrm{a}}$ Significant SNPs according the Bonferroni correction

${ }^{\text {b }}$ Suggestive SNPs

same. A further known region on chromosome $2 \mathrm{H}$ is located between the 2 regions detected in the current study. It includes loci in the positions $48 \mathrm{cM}$ [11], 50-51 cM [5]; $54.2-55.4 \mathrm{cM}$ [3], $55.5 \mathrm{cM}$ [18], 57.15 [8], 59.35 [8], and $62.7 \mathrm{cM}$ [26]. In addition, more distal loci were found on chromosome $2 \mathrm{H}$ by Amezrou et al. (2018) [8] (92.22 cM) and Richards et al. (2016) [17] (120.04-125.35 cM).

\section{Chromosome 3H}

Three regions associated with different isolates were revealed on chromosome $3 \mathrm{H}$. The locus in the interval 12.117.4 cM between markers JHI-Hv50k-2016-156539 and JHI-Hv50k-2016-156594 was significantly associated with resistance to the P3.4.0 isolate. The closest locus among the QTLs mapped earlier is the locus at $8.5 \mathrm{cM}$ reported by Vatter et al. (2017) [18]. It is suggested that the region revealed in the current study between 12.1 and $17.4 \mathrm{cM}$ may carry a novel locus not described earlier. A further region associated with markers JHI-Hv50k-2016-183207, JHIHv50k-2016-169338, and SCRI_RS_186341 in the interval
50.9-54.8 cM was revealed for the A2.6.0 isolate. This region was earlier reported to be associated with net blotch resistance by Koladia et al. (2017) [9] (52.6-54.8 cM), Vatter et al. (2017) [18] (51.6 cM), and Wonneberger et al. (2017) [7] (46.2-54.5 cM). JHI-Hv50k-2016-183207 is located less than $500 \mathrm{~kb}$ from the marker SCRI_RS_221644 reported by Koladia et al. (2017) [9]. The locus associated with resistance to the K5.1 isolate included one suggestive SNP (JHI-Hv50k-2016-215624) mapped in the interval 135.6$137.5 \mathrm{cM}$. We suggest that seedling resistance to the K5.1 isolate is conferred by a previously known locus mapped earlier by Afanasenko et al. (2014) [2] and Amezrou et al. (2018) [8] (Table 5).

\section{Chromosome 6H}

The region on chromosome $6 \mathrm{H}$ between 52.6 and 55.4 $\mathrm{cM}$ was associated with resistance to three isolates (to P3.4.0 at the significant and K5.1 and S10.2 at the suggestive levels). Among the $12 \mathrm{SNPs}$ revealed in the current study is SCRI_RS_239642 and SCRI_RS_224389,

Table 3 Single nucleotide polymorphism (SNP) markers associated with resistance P3.4.0, A2.6.0, S10.2 and K5.1 isolates, revealed by GLM + PCA analysis according $p$-value

\begin{tabular}{|c|c|c|c|c|c|c|c|c|}
\hline Isolate & $\mathrm{p}$-value & Marker & chr & Position & $\mathrm{CM}$ & Allele & Minor Allele & SNP associated with resistance \\
\hline P3.4.0 & $3.24 \mathrm{e}-8$ & SCRI_RS_239642 ${ }^{a}$ & $6 \mathrm{H}$ & 357492232 & 55.4 & $A / G$ & $\mathrm{~A}(0.22)$ & $A(0.83)$ \\
\hline P3.4.0 & $4.84 \mathrm{e}-8$ & SCRI_RS_224389 ${ }^{a}$ & $6 \mathrm{H}$ & 360336381 & 55.4 & $\mathrm{C} / \mathrm{T}$ & $C(0.22)$ & $C(0.83)$ \\
\hline P3.4.0 & $7.42 \mathrm{E}-06$ & $J H I-H v 50 k-2016-104859^{b}$ & $2 \mathrm{H}$ & 639342580 & 71-74.1 & $A / G$ & $\mathrm{G}(0.18)$ & $\mathrm{A}(0.50)$ \\
\hline P3.4.0 & $1.44 \mathrm{E}-05$ & BOPA2_12_31445 b & $2 \mathrm{H}$ & 639288665 & $71-74.1$ & $A / G$ & $G(0.20)$ & $A(0.50)$ \\
\hline$A 2.6 .0$ & $2.08 \mathrm{E}-06$ & JHI-Hv50k-2016-169338c & $3 \mathrm{H}$ & 213632124 & $50.9-52.6$ & $A / G$ & $\mathrm{G}(0.40)$ & $G(0.92)$ \\
\hline A2.6.0 & 5.96E-06 & SCRI_RS_186341 ${ }^{\mathrm{C}}$ & $3 \mathrm{H}$ & NA & 51.2 & $\mathrm{G} / \mathrm{A}$ & $\mathrm{A}(0.40)$ & $A(0.92)$ \\
\hline S10.2 & $2.20 \mathrm{E}-06$ & $J H I-H v 50 k-2016-392656^{c}$ & $6 \mathrm{H}$ & 153234073 & $52.6-53.8$ & $\mathrm{C} / \mathrm{T}$ & $C(0.48)$ & $\mathrm{T}(0.86)$ \\
\hline S10.2 & $2.38 \mathrm{E}-06$ & $J H I-H v 50 k-2016-391875^{c}$ & $6 \mathrm{H}$ & 142513704 & & $\mathrm{~A} / \mathrm{C}$ & $A(0.30)$ & $C(1)$ \\
\hline S10.2 & $2.38 \mathrm{E}-06$ & BOPA2_12_30021 ${ }^{\mathrm{C}}$ & $6 \mathrm{H}$ & 156957594 & & $\mathrm{~A} / \mathrm{G}$ & $A(0.30)$ & $G(1)$ \\
\hline K5.1 & 2.84E-05 & JHI-Hv50k-2016-215624 & $3 \mathrm{H}$ & 668951958 & $135.6-137-5$ & $\mathrm{~A} / \mathrm{C}$ & $C(0.11)$ & $A(1)$ \\
\hline K5.1 & $3.14 \mathrm{E}-05$ & SCRI_RS_239642 ${ }^{c}$ & $6 \mathrm{H}$ & 357492232 & 55.4 & $A / G$ & $A(0.22)$ & $A(0.55)$ \\
\hline
\end{tabular}

${ }^{\mathrm{a}}$ Significant SNPs according the Bonferroni correction

bSignificant SNPs according the FDR

'Suggestive SNPs 
Table 4 Single nucleotide polymorphism (SNP) markers associated with resistance P3.4.0, S10.2 and K5.1 isolates, revealed by GLM + $\mathrm{PCA}+\mathrm{Q}$ analysis according $\mathrm{p}$-value

\begin{tabular}{|c|c|c|c|c|c|c|c|c|}
\hline Isolate & $p$-value & Marker & chr & Position & $\mathrm{CM}$ & Allele & Minor Allele & SNP associated with resistance \\
\hline P3.4.0 & $7.64 \mathrm{E}-07$ & SCRI_RS_239642 ${ }^{\mathrm{a}}$ & $6 \mathrm{H}$ & 357492232 & 55.4 & $A / G$ & $\mathrm{~A}(0.22)$ & $\mathrm{A}(0.83)$ \\
\hline P3.4.0 & $6.72 \mathrm{E}-07$ & SCRI_RS_224389 & $6 \mathrm{H}$ & 360336381 & 55.4 & $\mathrm{C} / \mathrm{T}$ & $C(0.22)$ & $C(0.83)$ \\
\hline P3.4.0 & 2.30E-07 & $J H I-H v 50 k-2016-104859^{a}$ & $2 \mathrm{H}$ & 639342580 & $71-74.1$ & $A / G$ & $G(0.18)$ & $A(0.50)$ \\
\hline P3.4.0 & $1.58 \mathrm{E}-06$ & BOPA2_12_31445 & $2 \mathrm{H}$ & 639288665 & $71-74.1$ & $A / G$ & $G(0.20)$ & $A(0.50)$ \\
\hline P3.4.0 & $9.13 \mathrm{E}-06$ & JHI-Hv50k-2016-35839 b & $1 \mathrm{H}$ & 463250609 & $62.3-62.8$ & $\mathrm{~T} / \mathrm{G}$ & $\mathrm{T}(0.38)$ & $G(0.75)$ \\
\hline P3.4.0 & 1.60E-05 & JHI-Hv50k-2016-398663 & $6 \mathrm{H}$ & 359349968 & 55.4 & $\mathrm{~T} / \mathrm{C}$ & $C(0.25)$ & $C(0.83)$ \\
\hline P3.4.0 & 1.60E-05 & SCRI_RS_138529 & $6 \mathrm{H}$ & 86866524 & 55.4 & $\mathrm{~T} / \mathrm{C}$ & $C(0.25)$ & $C(0.83)$ \\
\hline P3.4.0 & $2.59 \mathrm{E}-05$ & JHI-Hv50k-2016-104508 & $2 \mathrm{H}$ & 638564394 & $71-74.1$ & $\mathrm{C} / \mathrm{T}$ & $\mathrm{T}(0.24)$ & $\mathrm{T}(0.50)$ \\
\hline P3.4.0 & $2.59 \mathrm{E}-05$ & $J H I-H v 50 k-2016-104565^{b}$ & $2 \mathrm{H}$ & 638636071 & & $\mathrm{C} / \mathrm{T}$ & $\mathrm{T}(0.24)$ & $\mathrm{T}(0.50)$ \\
\hline P3.4.0 & $2.59 \mathrm{E}-05$ & $\mathrm{JHI}-\mathrm{Hv} 50 \mathrm{k}-2016-104567^{\mathrm{b}}$ & $2 \mathrm{H}$ & 638636277 & & $\mathrm{C} / \mathrm{T}$ & $\mathrm{T}(0.24)$ & $\mathrm{T}(0.50)$ \\
\hline P3.4.0 & $2.59 \mathrm{E}-05$ & JHI-Hv50k-2016-104667 & $2 \mathrm{H}$ & 638690222 & & $\mathrm{G} / \mathrm{T}$ & $\mathrm{T}(0.24)$ & $\mathrm{T}(0.50)$ \\
\hline P3.4.0 & 2.82E-05 & $J H I-H v 50 k-2016-104669^{b}$ & $2 \mathrm{H}$ & 638690416 & & $\mathrm{~A} / \mathrm{C}$ & $C(0.24)$ & $A(0.50)$ \\
\hline P3.4.0 & 4.35E-05 & JHI-Hv50k-2016-33086 & $1 \mathrm{H}$ & 438893078 & $57.3-58.2$ & $\mathrm{C} / \mathrm{A}$ & $A(0.26)$ & $C(0.75)$ \\
\hline P3.4.0 & 4.64E-05 & JHI-Hv50k-2016-156591 ${ }^{\mathrm{b}}$ & $3 \mathrm{H}$ & 17271039 & $12.1-17.4$ & $\mathrm{~T} / \mathrm{C}$ & $C(0.23)$ & $\mathrm{T}(0.75)$ \\
\hline P3.4.0 & 4.77E-05 & JHI-Hv50k-2016-156539 & $3 \mathrm{H}$ & 16631590 & & $\mathrm{G} / \mathrm{T}$ & $\mathrm{T}(0.14)$ & $G(0.75)$ \\
\hline P3.4.0 & 4.77E-05 & $J H I-H v 50 k-2016-156576^{b}$ & $3 \mathrm{H}$ & 17177586 & & $\mathrm{~T} / \mathrm{C}$ & $C(0.14)$ & $\mathrm{T}(0.75)$ \\
\hline P3.4.0 & 4.77E-05 & JHI-Hv50k-2016-156584 & $3 \mathrm{H}$ & 17269072 & & $C / G$ & $C(0.14)$ & $G(0.75)$ \\
\hline P3.4.0 & 5.54E-05 & JHI-Hv50k-2016-33097 ${ }^{\mathrm{b}}$ & $1 \mathrm{H}$ & 439174674 & $57.3-58.2$ & $\mathrm{G} / \mathrm{A}$ & $A(0.27)$ & $G(0.75)$ \\
\hline P3.4.0 & 5.54E-05 & JHI-Hv50k-2016-33109 & $1 \mathrm{H}$ & 439297538 & & $\mathrm{G} / \mathrm{A}$ & $A(0.27)$ & $C(0.75)$ \\
\hline P3.4.0 & $6.58 \mathrm{E}-05$ & JHI-Hv50k-2016-156594 & $3 \mathrm{H}$ & 17292680 & $12.1-17.4$ & $\mathrm{~A} / \mathrm{T}$ & $\mathrm{T}(0.22)$ & $A(0.75)$ \\
\hline P3.4.0 & $6.66 \mathrm{E}-05$ & JHI-Hv50k-2016-156586 & $3 \mathrm{H}$ & 17270441 & & $\mathrm{~T} / \mathrm{A}$ & $\mathrm{T}(0.23)$ & $A(0.75)$ \\
\hline P3.4.0 & 7.32E-05 & JHI-Hv50k-2016-33099 b & $1 \mathrm{H}$ & 439176975 & $57.3-58.2$ & $\mathrm{C} / \mathrm{T}$ & $T(0.26)$ & $C(0.75)$ \\
\hline P3.4.0 & 7.32E-05 & $\mathrm{JHI}-\mathrm{H} v 50 \mathrm{k}-2016-33104^{\mathrm{b}}$ & $1 \mathrm{H}$ & 439177729 & & $\mathrm{~T} / \mathrm{C}$ & $C(0.26)$ & $\mathrm{T}(0.75)$ \\
\hline P3.4.0 & 7.59E-05 & JHI-Hv50k-2016-398720 b & $6 \mathrm{H}$ & 359701468 & 55.4 & $C / T$ & $\mathrm{~T}(0.10)$ & $C(0.58)$ \\
\hline P3.4.0 & 7.59E-05 & JHI-Hv50k-2016-398886 & $6 \mathrm{H}$ & 361528770 & & $\mathrm{C} / \mathrm{T}$ & $C(0.10)$ & $\mathrm{T}(0.58)$ \\
\hline P3.4.0 & 7.59E-05 & JHI-Hv50k-2016-398894 & $6 \mathrm{H}$ & 361531190 & & $\mathrm{C} / \mathrm{T}$ & $C(0.10)$ & $\mathrm{T}(0.58)$ \\
\hline P3.4.0 & $9.74 \mathrm{E}-05$ & $J H I-H v 50 k-2016-33120^{b}$ & $1 \mathrm{H}$ & 439541073 & $57.3-58.2$ & $\mathrm{C} / \mathrm{G}$ & $\mathrm{G}(0.27)$ & $C(0.75)$ \\
\hline P3.4.0 & $1.01 \mathrm{E}-04$ & $J H I-H v 50 k-2016-36398^{b}$ & $1 \mathrm{H}$ & 467931082 & $62.3-62.8$ & $\mathrm{~T} / \mathrm{G}$ & $\mathrm{G}(0.27)$ & $\mathrm{T}(0.83)$ \\
\hline S10.2 & 1.10E-05 & $J H I-H v 50 k-2016-392723^{c}$ & $6 \mathrm{H}$ & 155949390 & $52.6-53.8$ & $A / G$ & $\mathrm{G}(0.48)$ & $A(0.86)$ \\
\hline S10.2 & 1.10E-05 & JHI-Hv50k-2016-393052 & $6 \mathrm{H}$ & 163763506 & & $\mathrm{~T} / \mathrm{A}$ & $\mathrm{T}(0.48)$ & $A(0.86)$ \\
\hline S10.2 & $2.98 \mathrm{E}-05$ & $J H I-H v 50 k-2016-392656^{c}$ & $6 \mathrm{H}$ & 153234073 & & $\mathrm{~A} / \mathrm{G}$ & $\mathrm{A}(0.47)$ & $\mathrm{T}(0.86)$ \\
\hline S10.2 & 7.02E-05 & $J H I-H v 50 k-2016-391875^{c}$ & $6 \mathrm{H}$ & 142513704 & & $\mathrm{~A} / \mathrm{C}$ & $A(0.30)$ & $C(1)$ \\
\hline S10.2 & $7.02 \mathrm{E}-05$ & BOPA2_12_30021 ${ }^{\mathrm{C}}$ & $6 \mathrm{H}$ & 156957594 & & $A / G$ & $\mathrm{~A}(0.30)$ & $G(1)$ \\
\hline K5.1 & $1.41 \mathrm{E}-04$ & $J H I-H v 50 k-2016-215624^{c}$ & $3 \mathrm{H}$ & 668951958 & $135.6-137.5$ & $\mathrm{~A} / \mathrm{C}$ & $C(0.11)$ & $A(1)$ \\
\hline K5.1 & $1.45 \mathrm{E}-04$ & $\mathrm{JHI}-\mathrm{Hv} 50 \mathrm{k}-2016-33160^{c}$ & $1 \mathrm{H}$ & 441912080 & $57.3-58.2$ & $\mathrm{G} / \mathrm{A}$ & $\mathrm{A}(0.21)$ & $A(0.55)$ \\
\hline
\end{tabular}

${ }^{\mathrm{a}}$ Significant SNPs according the Bonferroni correction

bSignificant SNPs according the FDR

'Suggestive SNPs

reported earlier to be associated with NFNB resistance $[17,18]$. The presence of QTL for NFNB resistance in barley chromosome $6 \mathrm{H}$ was reported in several studies. First, this locus was found by Steffenson et al. (1996) [3], then confirmed by Manninen et al. (2006) [27] and named RPt5. Wonneberger et al. (2017) [7] and Afanasenko et al. (2014) [2] revealed the genomic region associated with NFNB resistance in the same interval. Further loci were revealed close to this region $[5,16]$ (Table 5).

\section{Conclusions}

Seven genomic regions on chromosomes $1 \mathrm{H}, 2 \mathrm{H}, 3 \mathrm{H}$, and $6 \mathrm{H}$ associated with the resistance to four 
Table 5 Comparison of the regions associated with resistance to $P$. teres $f$. teres, identified in the current study and previous studies

\begin{tabular}{|c|c|c|c|c|c|}
\hline $\mathrm{chr}$ & Isolate & $\mathrm{p}$-value & Marker & CM & Previuosly identified QTLs (cM) \\
\hline \multirow[t]{9}{*}{$\overline{1 H}$} & P3.4.0 & $4.35 E-05$ & JHI-Hv50k-2016-33086 & \multirow[t]{9}{*}{$57.3-62.8$} & \multirow{9}{*}{$\begin{array}{l}\text { (52.4-56.8 cM) Grewal et al., } 2012 \text { [10]; } \\
\text { (50-86 cM) Afanasenko et al., } 2014 \text { [2]; } \\
\text { (92.2 cM) Amezrou et al., } 2018 \text { [8]; } \\
\text { (95.9 cM) Vatter et al. } 2017 \text { [18] }\end{array}$} \\
\hline & P3.4.0 & $5.54 \mathrm{E}-05$ & JHI-Hv50k-2016-33097 & & \\
\hline & P3.4.0 & $7.32 \mathrm{E}-05$ & JHI-Hv50k-2016-33099 b & & \\
\hline & P3.4.0 & $7.32 \mathrm{E}-05$ & $J H I-H v 50 k-2016-33104^{b}$ & & \\
\hline & P3.4.0 & $5.54 \mathrm{E}-05$ & JHI-Hv50k-2016-33109 & & \\
\hline & P3.4.0 & $9.74 \mathrm{E}-05$ & $\mathrm{JHI}-\mathrm{Hv} 50 \mathrm{k}-2016-33120^{\mathrm{b}}$ & & \\
\hline & K5.1 & 1.45E-04 & JHI-Hv50k-2016-33160 & & \\
\hline & P3.4.0 & $9.13 \mathrm{E}-06$ & JHI-Hv50k-2016-35839 & & \\
\hline & P3.4.0 & $1.01 \mathrm{E}-04$ & JHI-Hv50k-2016-36398 ${ }^{b}$ & & \\
\hline \multirow[t]{8}{*}{$2 \mathrm{H}$} & $\mathrm{S} 10.2$ & $1.82 \mathrm{E}-05$ & JHI-Hv50k-2016-74407c & $23.2-23.8$ & $\begin{array}{l}\text { (10-28.7 cM) Wonneberger et al., } 2017 \text { [7]; } \\
(8 \mathrm{cM}, 23 \mathrm{cM}) \text { Vatter et al. } 2017 \text { [18] }\end{array}$ \\
\hline & P3.4.0 & 2.59E-05 & JHI-Hv50k-2016-104508 b & \multirow[t]{7}{*}{ 71.0-74.1 } & \multirow{7}{*}{$\begin{array}{l}\text { (48 cM) Arru et al., } 2003 \text { [11]; } \\
\text { (50-51 cM) Grewal et al., } 2008 \text { [5]; } \\
\text { (54.2-55.4 cM) Steffenson et al., } 1996 \text { [3]; } \\
\text { (55.5 cM) Vatter et al. } 2017 \text { [18]; } \\
\text { (62.7 cM) Cakir et al., } 2011 \text { [26]; } \\
\text { (51-75 cM) Afanasenko et al., 2014 [2]; } \\
\text { (75-80 cM) König et al., } 2014 \text { [25]; } \\
\text { (57.15, 59.35 cM and 92.22 cM) Amezrou et al., } 2018 \text { [8]; } \\
\text { (120.04-125.35 cM) Richards et al., } 2016 \text { [17] }\end{array}$} \\
\hline & P3.4.0 & $2.59 \mathrm{E}-05$ & $J H I-H v 50 k-2016-104565^{b}$ & & \\
\hline & P3.4.0 & $2.59 \mathrm{E}-05$ & JHI-Hv50k-2016-104567 & & \\
\hline & P3.4.0 & $2.59 \mathrm{E}-05$ & JHI-Hv50k-2016-104667 b & & \\
\hline & P3.4.0 & 2.82E-05 & JHI-Hv50k-2016-104669 b & & \\
\hline & P3.4.0 & $1.58 \mathrm{E}-06$ & BOPA2_12_31445 ${ }^{\mathrm{a}}$ & & \\
\hline & P3.4.0 & $2.30 \mathrm{E}-07$ & JHI-Hv50k-2016-104859a & & \\
\hline \multirow[t]{10}{*}{$3 \mathrm{H}$} & P3.4.0 & 4.77E-05 & JHI-Hv50k-2016-156539 b & \multirow[t]{6}{*}{$12.1-17.4$} & \multirow[t]{6}{*}{ (8.5 cM) Vatter et al. 2017 [18]; } \\
\hline & P3.4.0 & 4.77E-05 & JHI-Hv50k-2016-156576 & & \\
\hline & P3.4.0 & 4.77E-05 & JHI-Hv50k-2016-156584b & & \\
\hline & P3.4.0 & $6.66 \mathrm{E}-05$ & JHI-Hv50k-2016-156586b & & \\
\hline & P3.4.0 & 4.64E-05 & JHI-Hv50k-2016-156591 b & & \\
\hline & P3.4.0 & $6.58 \mathrm{E}-05$ & JHI-Hv50k-2016-156594 & & \\
\hline & A2.6.0 & $2.08 \mathrm{E}-06$ & JHI-Hv50k-2016-169338c & \multirow[t]{3}{*}{$50.9-54.8$} & \multirow{3}{*}{$\begin{array}{l}\text { (52.6-54.8 cM) Koladia et al.,2017 [9]; } \\
\text { (51.6 cM) Vatter et al. } 2017 \text { [18]; } \\
\text { (46.2-54.5 cM) Wonneberger et al., } 2017 \text { [7] }\end{array}$} \\
\hline & $A 2.6 .0$ & 5.96E-06 & SCRI_RS_186341 C & & \\
\hline & A2.6.0 & $1.01 \mathrm{E}-06$ & JHI-Hv50k-2016-183207ª & & \\
\hline & K5.1 & $1.41 \mathrm{E}-04$ & $J H I-H v 50 k-2016-215624^{c}$ & $135.6-137.5$ & $\begin{array}{l}\text { (115-119 cM) Grewal et al., } 2008 \text { [5]; } \\
\text { (112-150 cM) Afanasenko et al., } 2014 \text { [2]; } \\
\text { (137,6 cM) Amezrou et al., } 2018 \text { [8] }\end{array}$ \\
\hline \multirow[t]{13}{*}{$6 \mathrm{H}$} & P3.4.0 & $1.60 \mathrm{E}-05$ & SCRI_RS_138529 & \multirow[t]{13}{*}{$52.6-55.4$} & \multirow{13}{*}{$\begin{array}{l}\text { (50.8-66.4) Wonneberger et al., } 2017 \text { [7]; } \\
\text { (50.2-58.4 cM) Koladia et al., 2017 [9]; } \\
\text { (58 cM) Afanasenko et al., } 2014 \text { [2]; } \\
\text { (60-65 cM) König et al., 2014 [25]; } \\
\text { (75-78 cM) Grewal et al., } 2008 \text { [5] }\end{array}$} \\
\hline & $\mathrm{S} 10.2$ & $2.38 \mathrm{E}-06$ & JHI-Hv50k-2016-391875 & & \\
\hline & $\mathrm{S} 10.2$ & $2.20 \mathrm{E}-06$ & JHI-Hv50k-2016-392656 c & & \\
\hline & $\$ 10.2$ & $1.10 \mathrm{E}-05$ & JHI-Hv50k-2016-392723c & & \\
\hline & $\mathrm{S} 10.2$ & $2.38 \mathrm{E}-06$ & BOPA2_12_30021 ${ }^{\mathrm{C}}$ & & \\
\hline & S10.2 & 1.10E-05 & JHI-Hv50k-2016-393052 c & & \\
\hline & P3.4.0 & $3.24 \mathrm{E}-08$ & SCRI_RS_239642 ${ }^{\mathrm{a}}$ & & \\
\hline & K5.1 & $3.14 \mathrm{E}-05$ & SCRI_RS_239642 ${ }^{C}$ & & \\
\hline & P3.4.0 & $1.60 \mathrm{E}-05$ & JHI-Hv50k-2016-398663 b & & \\
\hline & P3.4.0 & $7.59 \mathrm{E}-05$ & JHI-Hv50k-2016-398720 b & & \\
\hline & P3.4.0 & 4.84E-08 & SCRI_RS_224389 & & \\
\hline & P3.4.0 & 7.59E-05 & JHI-Hv50k-2016-398886 b & & \\
\hline & P3.4.0 & 7.59E-05 & JHI-Hv50k-2016-398894 & & \\
\hline
\end{tabular}

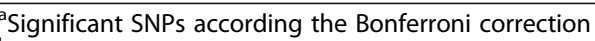

${ }^{\mathrm{b}}$ Significant SNPs according the FDR

'Suggestive SNPs

Our loci that were confirmed by literature data are in bold 
Pyrenophora teres $\mathrm{f}$. teres isolates were identified in a genome-wide association study of Siberian spring barley panel. One novel isolate-specific locus on chromosome 3 between 12.1 and $17.4 \mathrm{cM}$ was revealed. Other regions identified in the current study coincided with previously known loci conferring resistance to net blotch. The significant SNPs revealed in the current study can be converted to convenient PCR-markers for accelerated breeding of resistant barley cultivars.

\section{Additional files}

Additional file 1: Table with results of net blotch resistance assessment within the Siberian spring barley collection. HR - highly resistant (1.0-3.0); MR - moderately resistant (3.1-5.0); MS - moderately susceptible (5.1-6.9); S - susceptible (7.0-10.0); "-" - failed. (DOCX 43 kb)

Additional file 2: QQ-plots (quantile-quantile plots) for the models: (1) GLM without correction for population structure; (2) GLM + Q: GLM + Qmatrix to account for population structure; (3) GLM + PCA, (4) GLM + PCA $+\mathrm{Q}$ (5) MLM + K: MLM with kinship matrix. (DOCX 255 kb)

Additional file 3: Association mapping results using different models: $G L M+Q(G L M+Q$-matrix to account for population structure), GLM + $P C A, G L M+P C A+Q, M L M+K(M L M$ with kinship matrix). Dash line named "Bonferroni" corresponds the Bonferroni threshold. Dash line named "FDR" corresponds the FDR (false discovered rate) threshold. (DOCX 5895 kb)

\section{Abbreviation}

AM: Association mapping; FDR: False discovery rate; GLM: General linear model; GWAS: Genome-wide association study; HR: High resistant; HS: High susceptible; IRs: Infection responses; MLM: Mixed linear model; MR: Moderate resistant; MS: Moderate susceptible; NFNB: Net form net blotch: PCA: Principal component analysis; Q: Population structure; QO plot: Quantile-quantile plot; QTL: Quantitative trait locus; SFNB: Spot form net blotch; SNP: Single nucleotide polymorphism

\section{Acknowledgements}

We thank the ICG collection "GenAgro" (Novosibirsk, Russia) and personally Tatiana Kukoeva and Yuri Grigoryev, who formed and provided the spring barley core collection. We also thank Traitgenetics GmbH (Gatersleben, Germany) for providing service on genotyping of barley cultivars and lines using $50 \mathrm{~K}$ Illumina SNP-chip.

\section{Funding}

Growth of barley plants in the ICG Plant Growth Core Facility was supported by ICG project 0324-2019-0039. Publication costs was covered by the Russian Science Foundation (№ 16-14-00086).

\section{Availability of data and materials}

Not applicable.

\section{About this supplement}

This article has been published as part of BMC Genomics Volume 20 Supplement 3, 2019: Selected articles from BGRSISB-2018: genomics. The full contents of the supplement are available online at https://bmcgenomics. biomedcentral.com/articles/supplements/volume-20-supplement-3.

\section{Authors' contributions}

IVR performed the population structure and GWAS and drafted the manuscript. NML assessed the infection response and participated in drafting the manuscript. ZSM and SAG participated in the GWAS. VME participated in the population structure analysis. EKK and OSA carried out the experimental design, contributed to interpretation of data and to revising the manuscript critically. All authors read and approved the final manuscript.
Ethics approval and consent to participate

Not applicable.

\section{Consent for publication}

Not applicable.

\section{Competing interests}

The authors declare that they have no competing interests.

\section{Publisher's Note}

Springer Nature remains neutral with regard to jurisdictional claims in published maps and institutional affiliations.

\section{Author details}

${ }^{1}$ Institute of Cytology and Genetics, Siberian Branch of the Russian Academy of Sciences, Lavrentjeva Ave. 10, Novosibirsk 630090, Russia. ${ }^{2}$ N.I. Vavilov All-Russian Research Institute of Plant Genetic Resources (VIR), St. Petersburg 190000, Russia. ${ }^{3}$ All-Russian Research Institute for Plant Protection, St. Petersburg 196608, Russia. ${ }^{4}$ Novosibirsk State University, Pirogova, 1 , Novosibirsk 630090, Russia.

Published: 8 May 2019

\section{References}

1. Tamang P, Neupane A, Mamidi S, Friesen T, Brueggeman R. Association mapping of seedling resistance to spot form net blotch in a worldwide collection of barley. Phytopathology. 2015;105:500-8. https://doi.org/10. 1094/PHYTO-04-14-0106-R.

2. Afanasenko O, Koziakov AV, Hedlay P, Lashina NM, Anisimova AV, Manninen $\mathrm{O}$, et al. Mapping of the loci Controling the resistance to Pyrenophora teres f. teres and Cochlibolus sativus in two double haploid barley population. Vavilov J Genet Breed. 2014;18:751-64.

3. Steffenson B, Hayes P, Kleinhofs A. Genetics of seedling and adult plant resistance to net blotch (Pyrenophora teres f. teres) and spot blotch (Cochliobolus sativus) in barley. Theor Appl Genet. 1996:92:552-8.

4. Burleigh JR, Tajani M, Seck M. Effects of Pyrenophora teres and weeds on barley yield and yield components. Ecol Epidemiol. 1988;78:295-9.

5. Grewal TS, Rossnagel B, Pozniak C, Scoles G. Mapping quantitative trait loci associated with barley net blotch resistance. Theor Appl Genet. 2008;116: 529-39

6. Martin A, Platz GJ, de Klerk D, Fowler RA, Smit F, Potgieter FG, Prins R. Identification and mapping of net form of net blotch resistance in south African barley. Mol Breed. 2018:38(5):53.

7. Wonneberger R, Ficke A, Lillemo M. Mapping of quantitative trait loci associated with resistance to net form net blotch (Pyrenophora teres f. teres) in a doubled haploid Norwegian barley population. PLoS One. 2017;12: e0175773.

8. Amezrou R, Pal R, Verma S, Chao S, Brueggeman RS. Genome-wide association studies of net form of net blotch resistance at seedling and adult plant stages in spring barley collection. Mol Breed. 2018;38:58.

9. Koladia VM, Faris JD, Brueggeman JK, Richards RS, Chao S. Genetic analysis of net form net blotch resistance in barley lines Clho 5791 and Tifang against a global collection of $P$. teres $f$. teres isolates. Theor Appl Genet. 2017;130:163-73.

10. Grewal TS, Rossnagel BG, Scoles GJ. Mapping quantitative trait loci associated with spot blotch and net blotch resistance in a doubled-haploid barley population. Mol Breed. 2012:30:267-79.

11. Arru L, Francia E, Pecchioni N. Isolate-specific QTLs of resistance to leaf

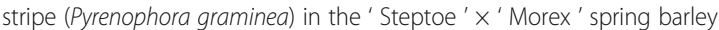
cross. Theor Appl Genet. 2003;106:668-75.

12. Ma Z, Lapitan NLV, Steffenson B. QTL mapping of net blotch resistance genes in a doubled-haploid population of six-rowed barley. Euphytica. 2004; 137:291-6.

13. Gupta S, Loughman R, Lance RCM. Identifying genetic complexity of $6 \mathrm{H}$ locus in barley conferring resistance to Pyrenophora teres $f$. teres. Plant Breed. 2011:130:423-9.

14. Berger GL, Liu S, Hall MD, Brooks WS, Chao S, Muehlbauer GJ, et al. Markertrait associations in Virginia Tech winter barley identified using genomewide mapping. Theor Appl Genet. 2013;126:693-710. 
15. Cakir MA, Gupta SB, Platz GJC, Ablett GAD, Loughman RB, Emebiri LCE, et al. Mapping and validation of the genes for resistance to Pyrenophora teres $f$. teres in barley (Hordeum vulgare L.). Aust J Agric Res. 2003;54:1369-77.

16. König J, Perovic D, Kopahnke D, Ordon F. Development of an efficient method for assessing resistance to the net type of net blotch (Pyrenophora teres f. teres) in winter barley and mapping of quantitative trait loci for resistance. Mol Breed. 2013;32:641-50. https://doi.org/10.1007/s11032-0139897-x.

17. Richards JK, Friesen TL, Brueggeman RS. Association mapping utilizing diverse barley lines reveals net form net blotch seedling resistance / susceptibility loci. Theor Appl Genet. 2017;130:915-27.

18. Vatter T, Maurer A, Kopahnke D, Perovic D, Ordon F, Pillen K. A nested association mapping population identifies multiple small effect QTL conferring resistance against net blotch (Pyrenophora teres $\mathrm{f}$. teres) in wild barley. PLoS One. 2017:12:e0186803.

19. Lehmensiek A, Platz GJ, Mace E, Poulsen D, Sutherland MW. Mapping of adult plant resistance to net form of net blotch in three Australian barley populations. Aust J Agric Res. 2008;58:1191-7.

20. Bykova IV, Lashina NM, Efimov VM, Afanasenko OS, Khlestkina EK. Identification of $50 \mathrm{~K}$ Illumina-chip SNPs associated with resistance to spot blotch in barley. BMC Plant Biol. 2017;17:250.

21. Cantalapiedra CP, Boudiar R, Casas AM, Igartua E, Contreras-Moreira B. BARLEYMAP: physical and genetic mapping of nucleotide sequences and annotation of surrounding loci in barley. Mol Breed. 2015:35:13.

22. Tekauz A. A numerical scale to classify reactions of barley to Pyrenophora Teres. Can J Plant Pathol. 1985:7:181-3.

23. Pritchard JK, Stephens M, Donnelly P. Inference of population structure using multilocus genotype data. Genetics. 2000;155:945-59.

24. Bradbury PJ, Zhang Z, Kroon DE, Casstevens TM, Ramdoss Y, Buckler ES. TASSEL: software for association mapping of complex traits in diverse samples. BIOINFORMATICS. 2007;23:2633-5.

25. König J, Perovic D, Kopahnke D, Ordon F. Mapping seedling resistance to net form of net blotch (Pyrenophora teres f. teres) in barley using detached leaf assay. Plant Breed. 2014;133:356-65. https://doi.org/10.1111/pbr.12147.

26. Cakir M, Gupta S, Li C, Hayden M, Mather DE, Ablett GA, et al. Genetic mapping and QTL analysis of disease resistance traits in the barley population Baudin x AC Metcalfe. Crop Pasture Sci. 2011:62:152-61.

27. Manninen OM, Jalli M, Kalendar R, Schulman A, Afanasenko O, Robinson J. Mapping of major spot-type and net-type net- blotch resistance genes in the Ethiopian barley line CI 9819. Genome. 2006;49:1564-71.

Ready to submit your research? Choose BMC and benefit from:

- fast, convenient online submission

- thorough peer review by experienced researchers in your field

- rapid publication on acceptance

- support for research data, including large and complex data types

- gold Open Access which fosters wider collaboration and increased citations

- maximum visibility for your research: over $100 \mathrm{M}$ website views per year

At $\mathrm{BMC}$, research is always in progress.

Learn more biomedcentral.com/submissions 